\title{
The Determination of Optimal Operating Condition For an Off-Grid Hybrid Renewable Energy Based Micro-Grid: A Case Study in Izmir, Turkey
}

\author{
Sezai Polat*, Hacer Sekerci \\ Electrical and Electronics Engineering Department, Engineering Faculty, \\ Yasar University, Izmir, Turkey \\ Email: sezaipolat@gmail.com, hacer.sekerci@yasar.edu.tr
}

Received February 15, 2021; Revised April 24, 2020; Accepted May 26, 2021

\begin{abstract}
Nowadays, off-grid systems, which do not require grid connection investment instead of grid connected systems, have become quite feasible. In this study, a feasibility analysis was carried out for a hybrid energy system using solar and wind energy sources to supply to uninterrupted electricity demand of a region with 100 villas in Izmir, Turkey. It has been shown that how changes cost of the hybrid energy system sizing according to the control strategies by using the HOMER software. In the paper, two different control strategies are determined as Cycle Charging (CC) and Load Following (LF), and then the control strategies are compared. According to the results obtained as a result of the simulations, it has been revealed that the research region to operate with CC can supply to the electrical energy demand with lower capacity system architecture. The CC was found to be more suitable for the research region than LF in terms of both Cost of Energy (COE) and Net Preset Cost (NPC).
\end{abstract}

Keywords: Hybrid system, Homer, Renewable energy, Control strategy, Energy cost, Optimization.

\section{INTRODUCTION}

With the rapid increase of technological developments today, many innovations that make human life easier and increase comfort have been added to our lives. It is inevitable to use energy with these innovations. However, despite the unlimited needs, energy resources reserves, which are the most important element of energy supply, are decreasing gradually. In this case, the search for new energy sources and directs the same time as necessary to more efficiently use existing energy sources [1]. Environmentally friendly designs become prominent day by day to provide lower cost and more efficient energy supply in order to ensure uninterrupted energy supply. The electric vitality frameworks around the world need to fulfill a persistently developing request for power and at the same time ensure stable offer [2]. Distributed generation which is near the load has become widespread for increasing energy supply and reliability with 
considering balance of demand and supply. If these conditions are not fulfilled, there will occur blackouts such as North-Eastern of USA in 2003, Indian in 2012, Turkey in 2015, Indonesia in 2019 and Argentina-ParaguayUruguay in 2019 [3]. As in the world, as seen in the Figure 1 renewable energy installed capacity in Turkey is increasing day by day.

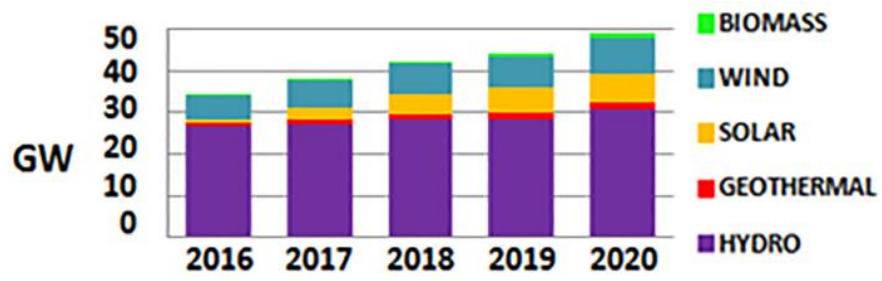

Figure 1. Development of installed capacity by years in Turkey[4]

Hybrid renewable energy sources (HRES) systems sometimes emerge to provide energy to places where energy is not available, sometimes to meet the need for low cost energy and sometimes as a government policy to reduce the amount of emissions [5]. In this study, a feasibility analysis is carried out to meet the electricity demands of a site which has a hundred villas in Izmir-Turkey province with renewable energy sources from solar and wind. Coordinates of the research area $\left(38^{\circ} 19.6^{\prime} \mathrm{N}, 26^{\circ} 46.0^{\prime} \mathrm{E}\right)$, energy resources for this region were taken into consideration and the data were analyzed. There are many rural settlements near the province of Izmir. Therefore, this geographic location has been chosen as the research location.

Villa type houses are very common in the region chosen in the study. Nowadays, due to the high preference of these types of settlements in the province of Izmir, the analyzed and proposed system can be easily applied. In other words, there are many hybrid energy system (HES) applications similarly such as solar home and with small wind turbine. Optimum hybrid energy system design is vital corresponding to capital and operational cost. In this study, it is aimed to improve the effect of different control strategy on energy cost while designing the system architecture and sizing of an off grid HES system.

\section{RELATED WORKS}

HRESs, which have been studied extensively recently, are emerging as a good method to ensure continuous energy continuity. Vital components of a micro grid are wind and solar which base on renewable energy resources. Hybrid energy systems are designed generally using Homer, Matlab, TRNSYS, RETScreen, iHOGA, and PVSyst software. Among these softwares, Homer simulation tools are most well-known and are utilized universally by analysts, specialists, and utility engineers. In the literature, there are many studies in which HRESs are suggested review and proposal. Sanini et al proposed design optimal system architecture for water treatment plant and also showed in low and fairly constant fuel price in the lifecycle of the project in Ref [6]. The HES design has been investigated in application areas 
according to different load types, which are domestic ones [7], industrial ones [8] and commercial ones [9],[10]. Similarly Elkadeem et al, in [11] was designed a grid-free system in a region in Egypt that needs $157 \mathrm{kWh}$ of electricity per day, and proposed a system to meet the thermal load requirement in addition to the electrical load. In the system designed with off grid, different system structures were analyzed and the most suitable system proposal was made by using renewable energy with appropriate system sizing. Sighn et al, in their paper, they proposed the most suitable system by using photovoltaic panels as an energy source in addition to biomass and fuel cell [12]. Abdin et al. in ref [13], they showed in which region and what kind of system architecture the system should have the most cost-effective system. They carried out this study for the purpose of generating electricity and hydrogen in five different cities located in different countries. In [14], the authors analyzed the system structure that achieved the lowest energy cost by analyzing a tracking photovoltaic system that grid connected. Veilleux et al. [15], in their study, examined how the energy cost was affected when AC and DC solar panels were designed with different battery types. In [16], the authors offered different geographical regions of Turkey which was installed $5 \mathrm{~kW}$ capacity of solar panels that analysis would be more profitable for investment.

\section{ORIGINALITY}

Most of the studies in the literature are researches for optimum sizing according to energy sources. Few of them are studies on determination of optimum operating conditions. These studies are about how an existing system can be operated optimally. Determining the optimum operating conditions of the system are very few studies determined that the sizing. The major contribution of this research paper is the only article in which the optimum size is calculated by determining the optimum operating conditions of the system by taking into account the energy resources of the study area, the solar and wind. Second, the uniqueness of this study is that for the hybrid energy system design, the data of two meteorological measurement institutions with different energy sources in the research area are compared and the design is made accordingly. Another contribution and difference from other articles is that it is an article in which the effect of control strategy on optimum sizing according to determined energy resources characteristics is shown.

The rest of organization of the paper is as below; section 4 presents the system design used in the study, section 5 discusses experiment and analysis, section 6 conclusion from the study.

\section{SYSTEM DESIGN}

\subsection{Materials and Methods}

In this study, HES system is modeled with HOMER software in order to meet the energy needs of villa-type houses located in Izmir, Turkey, and the 
system is compared in terms of economics and technical analysis in accordance with different control strategies. As a result, it will be decided to plan the most suitable system model.

Firstly, in order for the renewable energy to be used effectively, it is necessary to determine the continuity and size of the source with comprehensive analysis. For this reason, the renewable energy sources of the research area have been examined in detail.

\subsection{Potentials of the Region Solar and Wind Energy Resources}

Different data sources are used to examine the meteorological characteristics of the subject settlement. Average solar radiation, which is one of the important factors in determining the solar energy potential, has been studied for the power to be obtained from solar energy. The data of the solar energy potential obtain from the Turkey Solar Energy Potential Atlas (GEPA) published together by Republic of Turkey Ministry of Energy and Natural Resources and Turkish State Meteorological Service (TSMS) are shown for Izmir Province in Figure 2. Also, the graph showing the monthly change of solar radiation data for the area of study is shown in Figure 3(a). While the average yearly solar radiation value of Izmir Province is 4.13 $\mathrm{kWh} / \mathbf{m}^{2}$-day according to GEPA data, it is $5.08 \mathrm{kWh} / \mathbf{m}^{2}$-day according to NASA data. In the evaluation, it is seen that there is no significant difference between the GEPA data and the NASA data. NASA data, which is widely used in the literature, have been used to compare and validate with studies to be conducted in different geography parts of the world. The Figure 3(b) shows the monthly global solar change of the region, where the green line indicates the monthly maximum and minimum values, the blue line indicates the average of the daily maximum and minimum values for that month, and the red line indicates the monthly average. As can be seen, the highest value was in June, while the lowest value was measured in December.

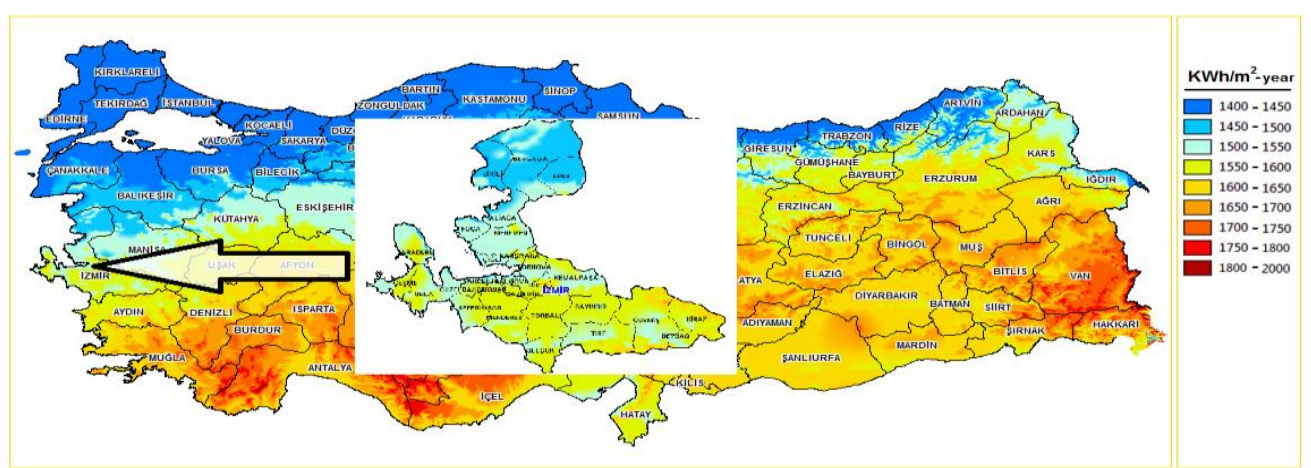

Figure 2. Geographical distribution of annual global solar irradiation [17]

According to REPA, a capacity factor of $35 \%$ or above and $4 \mathrm{~m} / \mathrm{s}$ or above wind speed at 50 meters are required for an economical wind power plant investment [18]. It is seen that the capacity factor is at a sufficient level for Izmir, Turkey, which is the study area. In other words, there is enough wind speed for the establishment of a wind farm in the region. According to 
the Figure 4(a) since the annual average wind speed is greater than $4 \mathrm{~m} / \mathrm{s}$, it has the average required wind speed for the installation of a wind turbine, and it is suitable for investment. The Figure 4(a) shows the monthly wind speed change of the region, where the green line indicates the monthly max and min values, the blue line indicates the average of the daily max and min values for that month, and the red line indicates the monthly average. As can be seen, the highest value was in February, while the lowest value was measured in June.
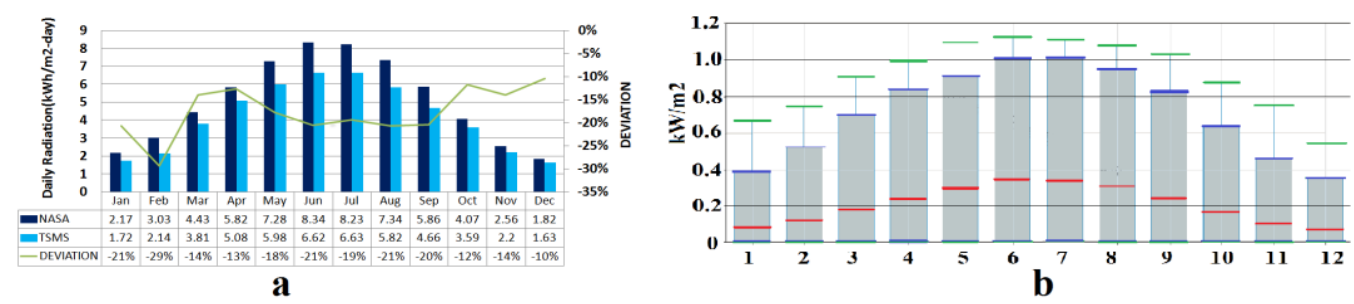

Figure 3. Average monthly a) solar irradiation [17], [19], b) global solar [19]

One of the factors affecting the efficiency of solar panels is ambient temperature. For this reason, the average temperature data of the months for the region given in Figure 4(b) affects the electricity generation of solar panels. Average temperature data are also considered in this paper.
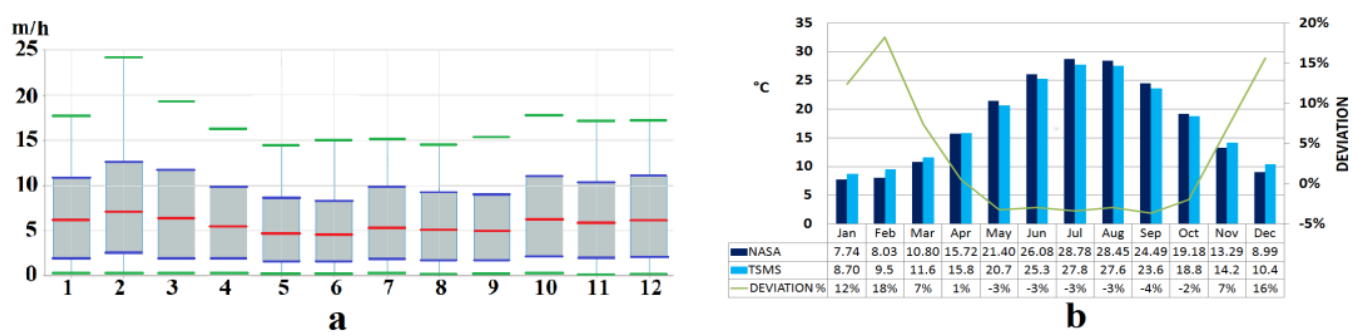

Figure 4. Average monthly a) wind speed [19], b) ambient temperature [17], [19]

It should be noted that the manufacturer's data of the PV panel are 25 ${ }^{\circ} \mathrm{C}$ in ambient temperature. For this reason, it should be taken into consideration that efficiency will decrease as the ambient temperature exceeds the test temperature specified by the manufacturer and the system capacity should be designed accordingly.

\subsection{Load Profile}

Load data [19] of 100 houses from the Pecan street dataset from January 2018 to December 2018 at 15 minutes resolution were used. The load profile selected in this study is assumed to be a site area with a hundred villas. In this load curve with the domestic load type, the hours with the highest demand are in the evening hours and the lowest are at night. In order to reveal the differences arising from the control strategy, the yearly load profile obtained from the literature was assumed to be in the study area. 
Since it generally has a warm climate in the research area, energy consumption is used for cooling purposes in contrast to heating. This caused the energy consumption to be generally high during the summer months.

In the Figure 5, the hourly variation of load, wind speed and irradiation in the monthly day is shown. As can be seen from the Figure 5, consumption around 05:00 was the lowest for the load months and reached the highest level around 17:30. The difference between these two consumption values is greater in summer, while it is very small in winters. This situation is very important for the supply-demand balance in terms of supplying the energy to generate. It can be seen that the consumption has not fallen below $50 \mathrm{~kW}$ during a year.

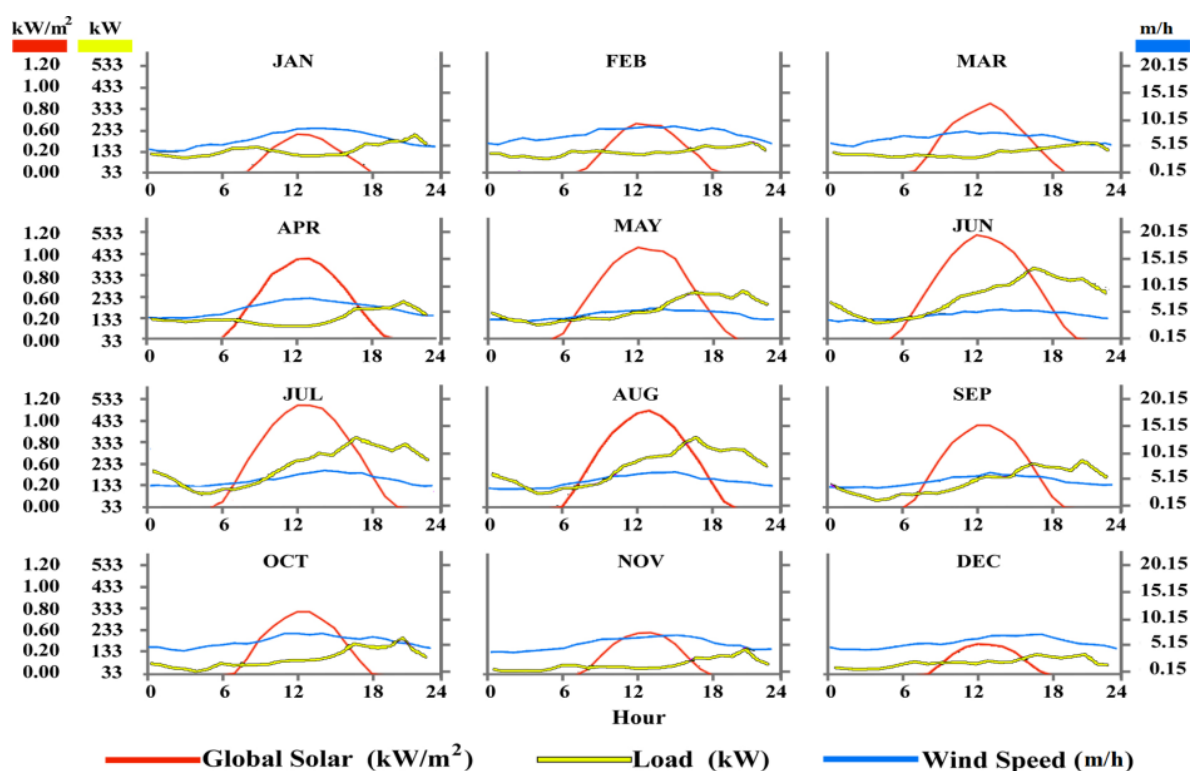

Figure 5. The average of hourly variation of load, solar irradiation and wind speed in the monthly [19], [20]

\subsection{Components Used In Hybrid Energy System}

The use of hybrid energy systems using multiple renewable energy sources is increasingly widespread to further reduce the cost of renewable energy sources and energy and to improve the quality of energy supply in today's energy systems. For this purpose, when an energy source is interrupted or insufficient, the other energy source is activated to ensure energy continuity.

\subsubsection{Photovoltaic Panel}

Solar panels, also known as photovoltaic panels, are energy system elements that can obtain DC output power directly from sunlight. Power equality is given in Equation (1) [21].

$$
\mathrm{P}_{\mathrm{pv}}=\mathrm{Y}_{\mathrm{pv}} \mathrm{f}_{\mathrm{pv}}\left(\frac{\mathrm{G}_{\mathrm{T}}}{\mathrm{G}_{\mathrm{T} . \mathrm{STC}}}\right)\left[1+\alpha_{\mathrm{p}}\left(\mathrm{T}_{\mathrm{C}}-\mathrm{T}_{\mathrm{c} . \mathrm{STC}}\right)\right]
$$


Where; $\mathrm{Y}_{\mathrm{pv}}$, maximum output power $(\mathrm{kW})$;

$\mathrm{f}_{\mathrm{pv}}$, panel degradation factor;

$\mathrm{G}_{\mathrm{T}}$, unit power generated by solar radiation in the solar panel $\left(\mathrm{kW} / \mathrm{m}^{2}\right)$;

$\mathrm{G}_{\mathrm{T} . \mathrm{STC}}$, standard test conditions $\left(\mathrm{kW} / \mathrm{m}^{2}\right)$;

$\alpha_{\mathrm{p}}$, temperature power coefficient $\left(\% /{ }^{\circ} \mathrm{C}\right)$;

$\mathrm{T}_{\mathrm{C}}, \mathrm{PV}$ cell temperature $\left({ }^{\circ} \mathrm{C}\right)$;

$\mathrm{T}_{\mathrm{C} . \mathrm{STC}}$, the standard solar panel test temperature $\left(25^{\circ} \mathrm{C}\right)$.

For the photovoltaic panel, which is one of the components of the hybrid energy systems, 72 (6x12) mono-crystal cell photovoltaic panels with a nominal power of $330 \mathrm{~W}$ were selected for this system. The specifications and costs of the PV are given in Table 1.

Table 1.Technical data of PV module [22], [23]

\begin{tabular}{|c|c|}
\hline Parameter & Specification \\
\hline Model & Peimar SG330P \\
\hline Power Rating & $330 \mathrm{~W}$ \\
\hline Temperature coefficient of power & -0.4 \\
\hline Operating temperature & 47 \\
\hline Module Efficiency & $\% 17$ \\
\hline Lifetime & 25 Year \\
\hline Capital Cost $(1 \mathrm{~kW})$ & $7,000 \$$ \\
\hline Replace $(1 \mathrm{~kW})$ & $7,000 \$$ \\
\hline O\&M $(1 \mathrm{~kW})$ & $10 \$$ \\
\hline
\end{tabular}

\subsubsection{Diesel Generator}

Diesel generator; It is a system element that converts diesel fuel into electrical energy as an auxiliary energy source within the proposed system architecture. Equation (2) contains the equation of the power of electrical energy generated as a function of the diesel fuel consumed [22].

$$
\mathrm{F}=\mathrm{F}_{0} \cdot \mathrm{Y}_{\text {gen }}+\mathrm{F}_{1} \cdot \mathrm{P}_{\text {gen }}
$$

Where; F, hourly fuel consumption (liter/hour);

$\mathrm{F}_{0}$, coefficient generator fuel curve (liter $/ \mathrm{hr} / \mathrm{kWh}$ rated);

$\mathrm{F}_{1}$, slope coefficient of the output power of fuel curve (liter $/ \mathrm{hr} / \mathrm{kWh} \mathrm{h}_{\text {output }}$ );

$\mathrm{Y}_{\mathrm{gen}}$, the nominal power of the generator $(\mathrm{kW})$;

$\mathrm{P}_{\text {gen }}$, the output power of generator unit $(\mathrm{kW})$.

It has been evaluated that it would be appropriate to include a diesel generator in the designed system in order to ensure the continuity of electrical energy as well as renewable energy. In the proposed system, Generac SD150 model diesel generator with a power generation capacity of $150 \mathrm{~kW}$ in the database of the Homer software was selected and their specifications and costs are given in Table 2 . The fuel price to be paid for a liter was assumed approximately 1 \$ in Turkey.

Six different emission types, namely Sulfur Dioxide (SO2), Carbon Monoxide (CO), Nitrogen Oxides (NOx), Unburned Hydrocarbons (UHC), Particulate Matter (PM), and Carbon Dioxide (CO2), belonging to a hybrid 
energy system in Homer software can be calculated. The emissions are directly related to fuel consumption. The average amount of carbon dioxide released from one liter of diesel fuel that is burnt completely is expressed as follows Equation (3);

$$
\text { emission }=\sum_{i} P_{D G_{i}} \times a_{i} \times 8760
$$

Where; $\mathrm{P}_{\mathrm{DG}_{\mathrm{i}}}$ is generator production, $\mathrm{a}_{\mathrm{i}}$ is emission rate of pollutant gases, $i$ is any hour.

Table 2. Specification of diesel generator [24]

\begin{tabular}{|c|c|c|}
\hline \multicolumn{2}{|r|}{ Parameter } & Specification \\
\hline \multicolumn{2}{|r|}{ Model } & Generac SD250 \\
\hline \multicolumn{2}{|r|}{ Power Rated } & $250 \mathrm{~kW}$ \\
\hline \multicolumn{2}{|c|}{ Fuel Consumption Rate } & 3.15 liter/hour \\
\hline \multicolumn{2}{|r|}{ Life time } & 150,000 hour \\
\hline \multirow{2}{*}{ Emission } & Carbon Monoxide & $17.79 \mathrm{gr} / \mathrm{liter}$ \\
\hline & Unburned Hydrocarbons & $0.72 \mathrm{gr} / \mathrm{liter}$ \\
\hline \multicolumn{2}{|r|}{ Capital Cost $(1 \mathrm{~kW})$} & $200 \$$ \\
\hline \multicolumn{2}{|r|}{ Replace (1 kW) } & $160 \$$ \\
\hline & $0 \& \mathrm{M}$ & $0.83 \$ /$ hour \\
\hline
\end{tabular}

\subsubsection{Wind Turbine}

A wind turbine converts wind energy into mechanical energy first and then mechanical energy into electrical energy. The equation for the power to be obtained from the wind turbine is given in Equation (4);

$$
\mathrm{P}=\frac{1}{2} \rho \mathrm{A}_{\mathrm{T}} \mathrm{V}^{3} \mathrm{C}_{\mathrm{p}}
$$

Where; $\mathrm{P}$ is the unit of wind turbine output power in watts (W), $\boldsymbol{\rho}$ is air density unit $\mathrm{kg} / \mathrm{m}^{3}, \mathrm{~A}_{\mathrm{T}}$ unit of area swept by the turbine $\mathrm{m}^{2}, v$ unit of wind speed $m / s, C_{p}$ is the power factor of the turbine [21]. The wind turbine control bend can be demonstrated with a third-degree in Eq(5);

$$
\mathrm{P}_{\mathrm{w}}(\mathrm{v})=\left\{\begin{array}{lr}
0, & v<v_{\text {cut-in }} \\
\left(\mathrm{f}_{1} v^{3}+\mathrm{f}_{2} v^{2}+\mathrm{f}_{3} v+\mathrm{f}_{4}\right) \mathrm{P}_{\mathrm{R}}, & v_{\text {cut-in }} \leq v<v_{\text {rated }} \\
\mathrm{P}_{\mathrm{R}}, & v_{\text {rated }} \leq v<v_{\text {cut-out }} \\
0, & v \geq v_{\text {cut-out }}
\end{array}\right.
$$

Where; $v$, wind speed $(\mathrm{m} / \mathrm{s})$;

$\mathrm{f}_{1}, \mathrm{f}_{2}, \mathrm{f}_{3}$ and $\mathrm{f}_{4}$ regression coefficient;

$\mathrm{P}_{\mathrm{w}}$, wind turbine rated power $(\mathrm{kW})$.

Since it is appropriate to use wind energy in the area where the study is conducted, wind turbine is also included in the proposed hybrid energy system. XANT21 model was selected for wind turbine to be used in the structure as a result of proposal system which can produce electrical energy in the $100 \mathrm{~kW}$ rated power. The properties and costs of the selected wind turbine are shown in Table 3. The Cut-in speed is the speed at which wind turbine is designed to start running. The "rated wind speed" is the wind speed at which the "rated power" is achieved. The wind turbine is designed 
to stop to avoid damaging the turbine or its surroundings. The stop wind speed is called the 'cut-out' wind speed. The average speed for all months is within the $\mathrm{v}_{\text {cut-in }}$ and $\mathrm{v}_{\text {cut-out }}$ limits for the wind turbine.

Table 3. Technical data of the wind turbine [23]

\begin{tabular}{|l|c|}
\hline Parameter & Specification \\
\hline Model & XANT M-21-ETR 100 \\
\hline Diameter & 21 meter \\
\hline Tower height & 31,8 meter \\
\hline Life time & 20 year \\
\hline Capital Cost $(1 \mathrm{~kW})$ & $1000 \$$ \\
\hline Replace $(1 \mathrm{~kW})$ & $800 \$$ \\
\hline O\&M $(1 \mathrm{~kW})$ & $20 \$$ \\
\hline
\end{tabular}

\subsubsection{Battery Bank}

TS HV 70-14 model battery group which was produced by Tesvolt Company was selected in order to store energy in the system when the load was low and production was high. The selected battery characteristics are shown in Table 4.

Table 4. Technical data of the battery [23], [25]

\begin{tabular}{|c|c|}
\hline Parameter & Specification \\
\hline Brand & Tesvolt \\
\hline Model & TS-HV70 67,2 kWh \\
\hline Operating voltage & 715 Volt \\
\hline Energy & $67,2 \mathrm{kWh} / 94 \mathrm{Ah}$ \\
\hline Life time & 30 Year or 8,000 full cycles \\
\hline Cells & Lithium \\
\hline Capital Cost $(100 \mathrm{kWh})$ & $70.000 \$$ \\
\hline Replace $(100 \mathrm{kWh})$ & $70.000 \$$ \\
\hline O\&M $(100 \mathrm{kWh})$ & $1 \$$ \\
\hline
\end{tabular}

\subsubsection{Converter}

Generic firm's System Converter model was chosen as AA-DA and DAAA converters, which are the basic components of energy systems. Table 5 shows the costs and characteristics of the converter.

Table 5. Technical data of the converter [22],

\begin{tabular}{|l|l|}
\hline Parameter & Specification \\
\hline Model & System Converter \\
\hline Invertor Eff. & $\% 95$ \\
\hline Rectifier Eff. & $\% 95$ \\
\hline Life time & 15 Year \\
\hline Capital Cost $(1 \mathrm{~kW})$ & $1.000 \$$ \\
\hline Replace $(1 \mathrm{~kW})$ & $1.000 \$$ \\
\hline O\&M $(1 \mathrm{~kW})$ & $10 \$$ \\
\hline
\end{tabular}




\subsubsection{Simulation Tool}

Homer software is a simulation tool that includes the selection and sizing of the components of the hybrid energy system. Thanks to this software, both long-term and short-term energy and economic analyzes of a designed system can be performed. HOMER software was also used for validation of the optimized results [26] indicating its wide acceptability.

\subsubsection{Optimization Procedure}

Meteorological data and load inputs are provided to determine how much energy it can generate from which energy source at which time and the load of that time. In addition, the characteristics of equipment such as PV panel, wind turbine, converter and battery to be used have been entered into the software. In addition, data inputs are completed by entering parameters such as capital cost, maintenance replacement cost, inflation, interest, which are necessary for the system economy. Figure 6 shows the complete flow diagram of selecting the size of PV panel and Wind Turbine. After the input information are entered into Homer simulation tool, designed sizes of hybrid energy system's equipment are decided in stages counting simulation, optimization and sensitivity examination as depicted in Figure 6 [27].

Since the designed system load is AC type and diesel generators and wind turbines also have AC output characteristics, an AC bus is designed in Homer software. A converter was used in order to connect the DC characteristic power produced by the photovoltaic panels and the battery group to the system. The system architecture belonging to the system model created in Homer software was simulated without grid connection.

\subsubsection{Control Strategy}

Although some researchers have proposed their own control strategies for the hybrid energy system, Cycle Charging (CC) and Load Following (LF) are the most common strategies in the literature. For this reason, although different control strategies can be created in the software, commonly used CC and LF strategies were used in this study. After the energy required to meet the load is met from renewable energy, when the energy resources are reduced or/and insufficient, if the energy is supplied from the battery and then from the generator, the capacity of the battery and the PV, converter and wind turbine capacities to supply it are determined according to the flow chart in Figure 6 results.

There are two control strategies commonly used in hybrid energy systems. With the Homer software, two different control strategies can be modeled as LF and CC. In the management of the "Load Following" strategy, renewable energy sources charge the battery, but generators do not charge the battery. In the management of the "Cycle Charging" strategy, each time the generators start to operate, they generate more energy than is needed to feed the load and this surplus energy charges the battery group [28]. Another of the prominent aims of this study is to show the effect of these choices on 
the sizing of the equipment that designed system architecture, when determining that how to operate the system during the sizing of the system to be designed.

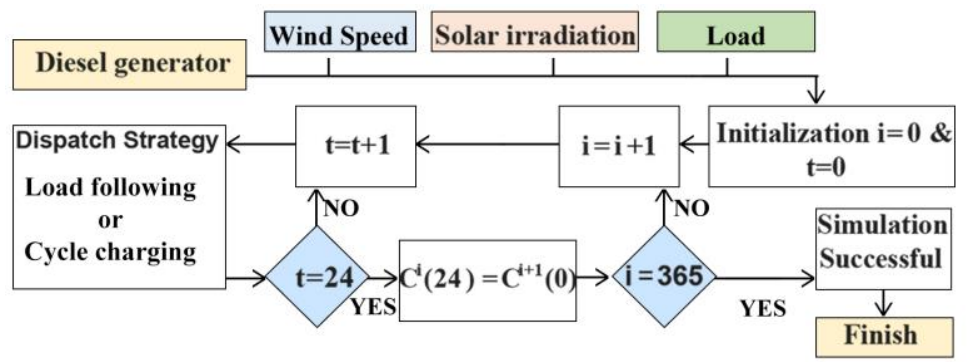

Figure 6. Flow chart of sizing method in Homer optimization procedure

a) In LF (Figure 7.a), renewable energy sources are used primarily to meet the demand of the load and also to charge the energy storage with excess energy. In case of an increase in the load, it is covered by renewable energy sources and energy storage (if SOC level is insufficient), otherwise the generator is activated and used. Here the DG is operated to meet the net load only.

b) In CC (Figure 7.b), renewable energy is used to first meet the demand and also to charge the batteries with excess energy. Any increase in the load is covered by renewable energy and batteries (if SOC level is insufficient), when it is not sufficient, a generator is operated. Here, the generator is used to meet the net load and also to charge the batteries. The flow chart of the two compared control strategies is shown in Figure 7.
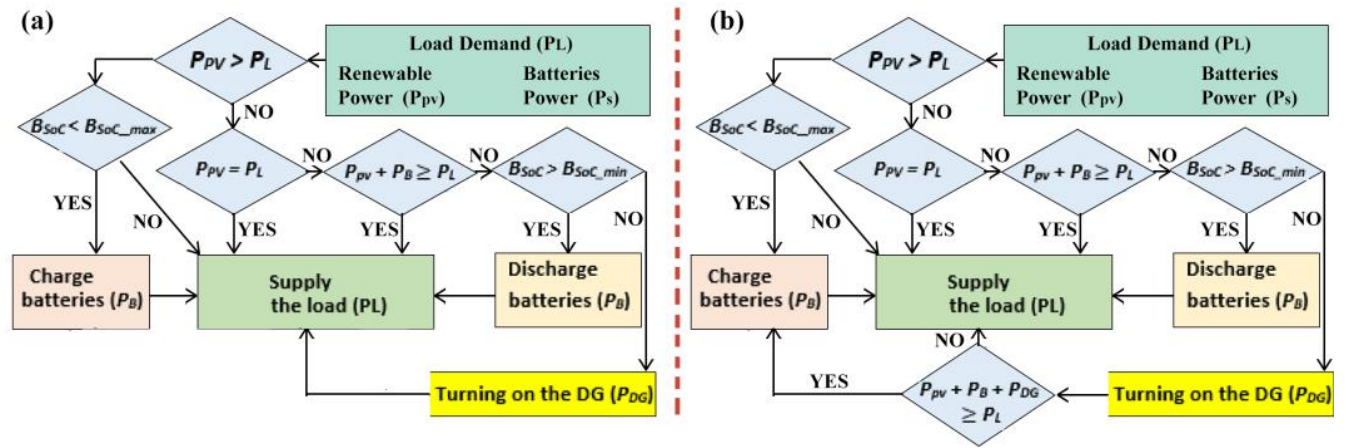

Figure 7. Flow chart of control strategies a) load following, b) cycle charging

\subsection{SYSTEM ECONOMICS}

The two principal economic elements, which are the total net present cost and the levelized cost of energy, depend on the total annualized cost of the system. HOMER Pro runs the optimization minimizes NPC and COE [29].

\subsubsection{Levelized Cost of Energy (COE)}

Homer Pro defines the levelized cost of energy as the average cost per kWh of useful electrical energy produced by the system [7]. The levelized 
cost of energy is the per kWh cost of the power plant over an assumed duty cycle is calculated as follows $\mathrm{Eq(6)}[29]$;

$$
\mathrm{COE}=\frac{\mathrm{C}_{\mathrm{T}}}{\mathrm{E}_{\mathrm{p}}+\mathrm{E}_{\mathrm{gs}}}(\$ / \mathrm{kWh})
$$

Where; $\mathrm{C}_{\mathrm{T}}$, the total annualized cost $(\$ / \mathrm{yr})$;

$\mathrm{E}_{\mathrm{p}}$, the amount of load the energy system supplied for per year (kWh/yr);

$\mathrm{E}_{\mathrm{gs}}$, the annual amount of energy supplied to the grid per year (kWh/yr).

\subsubsection{Net Present Costs (NPC)}

The total net present cost of a system is the present value of all the costs the system incurs over its lifetime, minus the present value of all the revenue it earns over its lifetime [30]. The aforementioned system economic parameters and calculations for both strategies are examined in Section 5.

\subsection{PROBLEM FORMULATION}

Problem formulation consists of objective function and constraints considered the same as:

\subsubsection{Objective function}

Net preset cost contains several costs such as capital, replacement, maintenance \& operation, fuel costs etc. Objective function is to determine net present cost by means of Homer of proposed system and is given by $\mathrm{Eq}(7)$

$$
\text { Objective function }=\min (\text { Net Present Cost }(N P C))
$$

$$
=C a C o+O \& M C+R C+F C
$$

Where; CaCo is the total capital cost, O\&MC, the total maintenance \& operation, $\mathrm{RC}$, the cost of replacement, $\mathrm{FC}$, the cost of fuel and all the system components.

\subsubsection{Constraints}

The following constraints are used to formulate the optimized objective function as $\mathrm{Eq}(8)$;

$$
\text { Subject to } \left.\sum \text { (load - power output }\right) \leq \max \text { unserved load }(\%) x \text { load }
$$

The capacity of a battery bank at any hour ' $\mathrm{t}$ ' lies in between minimum and maximum capacity. Then, the constraint is expressed as Eq(9); ;

$$
E_{\text {Batt }_{\min }} \leq E_{\text {Batt }_{(t)}} \leq E_{\text {Batt }} \text { max }
$$

\section{EXPERIMENT AND ANALYSIS}

Two different case studies were conducted by assuming same the load profile of 100 villas, wind and solar data of the selected area. Homer software 
calculates all possible possibilities and offers the lowest-priced system architecture economically. For the same research area, the determined wind, solar and load profiles were entered, only the control strategy was changed, for example, a design was made by considering the CC strategy flow diagram for case- 1 and the optimum system sizing was calculated. Similarly, for case2 , the LF strategy was calculated by determining its strategy in view of the flow diagram. In both cases, the requirement of the load was met by a combination of different sizes of PV, Wind, Battery and Generator. These two results obtained in this section are compared.

Case-1(CC): A hybrid system was designed in the Homer software as system which is not connected to the grid, and CC was chosen as the control strategy, and the following capacities were found as system recommendations. The capacities given in Table 6 have been calculated for this system designed considering CC and LF strategies. Accordingly the system architecture was designed to meet the determined load, including 1 diesel generator with 250 $\mathrm{kW}$ power, 9 battery groups which each has $67.2 \mathrm{kWh}$ capacity, solar panel capable of producing $649 \mathrm{kWp}$ power, 3 wind turbines with $100 \mathrm{~kW}$ power and $361 \mathrm{~kW}$ converter in power. The cost of energy to be produced with this system has been found as a result of $0.258 \$ / \mathrm{kWh}$.

Case-2(LF): Off-grid system was built in Homer software and LF was selected as the control strategy and the following capacities were found as the system. Accordingly, in order to meet the determined load, number 1 diesel generator which has $250 \mathrm{~kW}, 23$ battery groups which each has 67.2 $\mathrm{kWh}$ capacity, mount of solar panel which has $904 \mathrm{kWp}, 2$ wind turbines which have $100 \mathrm{~kW}$ power rape and mount of $249 \mathrm{~kW}$ converter were calculated. The cost of energy to be produced with this system has been calculated as $0.276 \$ / \mathrm{kWh}$.
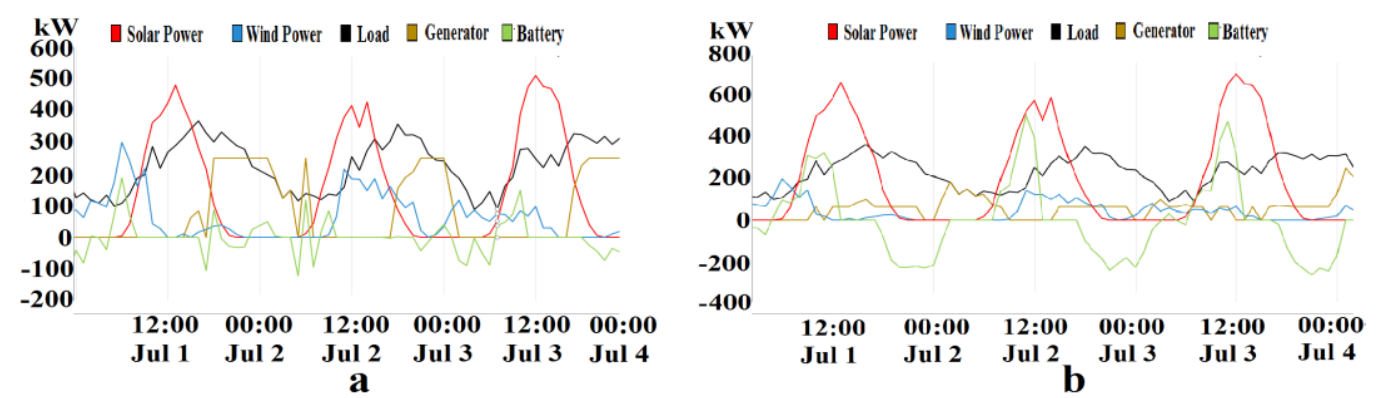

Figure 8. Energy generation-consumption between 1-4 July for a) Case-1, b) Case-2

As an example, the hourly production and consumption changes between 1-4 July are shown in Figure 8(a) and (b) according to LF and CC, respectively. As can be seen from the tables above, an improvement in system investment costs and energy costs can be achieved with two different strategies analyzed using the same renewable energy resources for the same geographical region. These results are illustrated comparatively in Table 7 . Although energy costs and investment costs seem to be lower in case-1, the system designed which is CC control strategy, it is seen that diesel fuel 
consumption is higher than case- 2 that is, the system designed which is LF control strategy.

Table 6. Cost and sizing analysis

\begin{tabular}{|l|l|l|l|r|r|}
\hline \multirow{2}{*}{ Equipment } & \multirow{2}{*}{ Model } & \multicolumn{2}{c|}{ Quantity } & \multicolumn{2}{c|}{ Capital Cost (\$) } \\
\cline { 3 - 6 } & & Case-1 & Case-2 & Case-1 & \multicolumn{1}{c|}{ Case-2 } \\
\hline Diesel Gen. & Genset 250 kW & 1 Unit & 1 Unit & 50,000 & 50,000 \\
\hline PV Panel & Peimar SG330P & $649 \mathrm{~kW}$ & $904 \mathrm{~kW}$ & 415,089 & 578,375 \\
\hline Battery & TS HV 70-67.2kWh & 9 strings & 23 strings & 846,900 & $2,160,000$ \\
\hline Wind Turb. & XANT M-21-ETR & 3 Unit & 2 Unit & 600,000 & 400,000 \\
\hline Converter & System Converter & $361 \mathrm{~kW}$ & $259 \mathrm{~kW}$ & 108,233 & 77,722 \\
\cline { 2 - 5 } & \multicolumn{3}{|c}{ Total } & $\mathbf{2 . 2 0} \mathbf{M}$ & $\mathbf{3 , 2 7}$ \\
\cline { 3 - 6 }
\end{tabular}

Table 7. Comparison of the control strategies results

\begin{tabular}{|c|c|c|c|}
\hline \multicolumn{2}{|c|}{ Dispatch Strategy } & Case-1 (CC) & Case-2 (LF) \\
\hline \multicolumn{2}{|c|}{ Generator number of starts (starts/year) } & 569 & 437 \\
\hline \multicolumn{2}{|c|}{ PV Production (kWh/year) } & $1,079,049$ & $1,503,521$ \\
\hline \multicolumn{2}{|c|}{ Wind Turb. Pro. (kWh/year) } & 599,695 & 399,796 \\
\hline \multicolumn{2}{|c|}{ Excess Electricity (kWh/year) } & 831,514 & 740,688 \\
\hline \multicolumn{2}{|c|}{ COE $(\$ / \mathrm{kWh})$} & 0.258 & 0.276 \\
\hline \multicolumn{2}{|c|}{ Fuel Consumption liter } & 148,151 & 72,228 \\
\hline \multirow{3}{*}{ Emissions } & $\mathrm{CO}_{2} \quad(\mathrm{~kg} /$ year $)$ & 387,500 & 188,917 \\
\hline & $\mathrm{CO} \quad(\mathrm{kg} /$ year $)$ & 2,636 & 1,285 \\
\hline & $\mathrm{SO}_{2} \quad(\mathrm{~kg} /$ year $)$ & 950 & 463 \\
\hline \multicolumn{2}{|c|}{ Battery Expected Life } & 19.3 year & 20.4 year \\
\hline \multirow{3}{*}{$\begin{array}{l}\text { Production } \\
\text { Summary }\end{array}$} & PV & $49.2 \%$ & $70.9 \%$ \\
\hline & Generator & $23.5 \%$ & $10.2 \%$ \\
\hline & Wind turbine & $27.3 \%$ & $18.9 \%$ \\
\hline \multicolumn{2}{|l|}{ NPC (\$) } & $4,432,191$ & $4,742,086$ \\
\hline \multicolumn{2}{|c|}{ Capital Expenditures (CAPEX) } & $2.02 \mathrm{M} \$$ & $3.27 \mathrm{M} \$$ \\
\hline \multicolumn{2}{|c|}{ Operational Expenditure (OPEX) } & $186,576 \$$ & $113.842 \$$ \\
\hline
\end{tabular}

As shown in the Figure 9, although the cash flow is low initially with CC, it reaches the same level at the 15th year, then LF remains lower. This situation reveals the importance of life span in design.

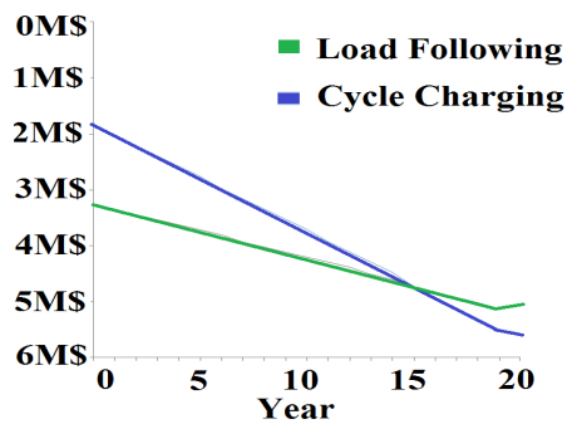

Figure 9. Cumulative Cash Flow for 20 year

\section{CONCLUSION}

In this study, system design and analysis was performed by taking into account parameters such as economy, efficiency, continuity and emissions in order to meet the energy demand. The most appropriate, economic and environmentally friendly system analyzes are performed by making analyzes such as the right selection of energy sources and equipment to be used when 
designing a hybrid energy system. In this paper, unlike other studies in the literature, it is aimed to show the effect of control strategy on sizing of hybrid energy system. As a result of the analysis, it was seen that CC was more suitable for both COE and NPC than LF for the geographical location where this study was conducted. COE, one of the most important parameters, was calculated as $0.258 \$ / \mathrm{kWh}$ with the CC control method, while with LF was found as $0.276 \$ / \mathrm{kWh}$. Similarly, CC with NPC and CAPEX were $4.432 \mathrm{M} \$$ and 2.2 $\mathrm{M} \$$ versus $4.742 \mathrm{M} \$$ and $3.27 \mathrm{M} \$$ with $\mathrm{LF}$, respectively. However, considering the parameters calculated as almost half, such as emissions, fuel consumption, LF emerged as a more suitable strategy than CC. Similar advantages were found battery life and operating cost,. Thus, the system, which appears to be more advantageous in the initial stage, that is, with low energy and investment costs, may become more disadvantageous over time.

These differences resulting from the implementation of these two control strategies may differ for each geographical region according to variation, average and total amount of renewable energy resources throughout the year. In summary, it is not possible to say that the two different control strategies analyzed are generally superior to one over the other. However, for every hybrid energy system designed, the optimal control strategy can be mentioned. One of the important criteria is that the control strategy is taken into account in hybrid energy system design while sizing of the system equipments.

\section{REFERENCES}

[1] S. Upadhyay and M. P. Sharma, "A review on configurations, control and sizing methodologies of hybrid energy systems," Renewable and Sustainable Energy Reviews, vol. 38, pp. 47-63, 2014.

[2] T. Strasser et al., "A Review of Architectures and Concepts for Intelligence in Future Electric Energy Systems," IEEE Transactions on Industrial Electronics, vol. 62, no. 4, pp. 2424-2438, 2015.

[3] S. Polat and H. Şekerci, "Dünyada ve Ülkemizde Önemli Elektrik Çöküntüleri," ETUK - National Congress and Exhibition of Electrical Installation, pp. 1-12.

[4] "Ministry of Energy and Natural Resources." https://enerji.gov.tr/renewable-energy (accessed Feb. 14, 2021).

[5] S. Polat and H. Sekerci, "Analysis of Economic Effects of Different Control Strategies in a Hybrid Energy System," in 2020 Innovations in Intelligent Systems and Applications Conference (ASYU), Oct. 2020, pp. $1-6$.

[6] S. O. Sanni, A. AWAISU, and T. S. AJAYI, "Optimal Design and Cost Analysis of Hybrid Autonomous Distributed Generation System for a Critical Load," EMITTER International Journal of Engineering Technology, vol. 6, no. 2, pp. 337-353, 2018.

[7] M. Bagheri, S. H. Delbari, M. Pakzadmanesh, and C. A. Kennedy, "Cityintegrated renewable energy design for low-carbon and climate- 
resilient communities," Applied Energy, vol. 239, pp. 1212-1225, 2019.

[8] M. O. Atallah, M. A. Farahat, M. E. Lotfy, and T. Senjyu, "Operation of conventional and unconventional energy sources to drive a reverse osmosis desalination plant in Sinai Peninsula, Egypt," Renewable Energy, vol. 145, pp. 141-152, 2020.

[9] M. Haratian, P. Tabibi, M. Sadeghi, B. Vaseghi, and A. Poustdouz, "A renewable energy solution for stand-alone power generation: A case study of KhshU Site-Iran," Renewable Energy, vol. 125, pp. 926935, 2018.

[10] E. Muh and F. Tabet, "Comparative analysis of hybrid renewable energy systems for off-grid applications in Southern Cameroons," Renewable Energy, vol. 135, pp. 41-54, 2019.

[11] M. R. Elkadeem, S. Wang, A. M. Azmy, E. G. Atiya, Z. Ullah, and S. W. Sharshir, "A systematic decision-making approach for planning and assessment of hybrid renewable energy-based microgrid with techno-economic optimization: A case study on an urban community in Egypt," Sustainable Cities and Society, vol. 54, p. 102013, 2020.

[12] A. Singh, P. Baredar, and B. Gupta, "Computational Simulation \&amp; Optimization of a Solar, Fuel Cell and Biomass Hybrid Energy System Using HOMER Pro Software," Procedia Engineering, vol. 127, pp. 743-750, 2015.

[13] Z. Abdin and W. Mérida, "Hybrid energy systems for off-grid power supply and hydrogen production based on renewable energy: $A$ techno-economic analysis," Energy Conversion and Management, vol. 196, pp. 1068-1079, 2019.

[14] H. Z. Al Garni, A. Awasthi, and M. A. M. Ramli, "Optimal design and analysis of grid-connected photovoltaic under different tracking systems using HOMER," Energy Conversion and Management, vol. 155, pp. 42-57, 2018.

[15] G. Veilleux et al., "Techno-economic analysis of microgrid projects for rural electrification: A systematic approach to the redesign of Koh Jik off-grid case study," Energy for Sustainable Development, vol. 54, pp. 1-13, 2020.

[16] A. C. Duman and Ö. Güler, "Economic analysis of grid-connected residential rooftop PV systems in Turkey," Renewable Energy, vol. 148, pp. 697-711, 2020.

[17] GEPA, "Solar energy potential atlas." https://gepa.enerji.gov.tr/MyCalculator (accessed Jun. 11, 2020).

[18] REPA, "Wind energy potential atlas." Accessed: Feb. 01, 2020. [Online]. Available: https://repa.enerji.gov.tr/REPA/iller/IZMIRREPA.pdf (accessed Jun. 11, 2020).

[19] “Pecan Street." https://dataport.pecanstreet.org/ (accessed May 09, 2021). 
[20] NASA-POWER, "NASA POWER, Prediction Of Worldwide Energy Resources." https://power.larc.nasa.gov/ (accessed Sep. 06, 2020).

[21] T. M. Azerefegn, R. Bhandari, and A. V. Ramayya, "Techno-economic analysis of grid-integrated $\mathrm{PV} /$ wind systems for electricity reliability enhancement in Ethiopian industrial park," Sustainable Cities and Society, vol. 53, p. 101915, 2020.

[22] HOMER Energy LLC, "HOMER Pro Version 3.7 User Manual," HOMER Energy. Colorado USA, p. 416, 2016, http://www.homerenergy.com/pdf/HOMERHelpManual.pdf (accessed Jan. 19, 2021).

[23] N. K. Kaynar, "Yenilenebilir Enerji Kaynaklarından Güneş Enerjisinin Amasya İlindeki Potansiyeli Potential of Solar Energy from Renewable Energy Sources in Amasya," Bilge International Journal of Science and Technology Research, pp. 48-54, 2020.

[24] "Generac Industrial Power - 250kW Diesel Generator-SD250." https://www.generac.com/Industrial/products/dieselgenerators/configured/250kw-diesel-generator (accessed May 13, 2021).

[25] Tesvolt, "High-voltage lithium storage system TS HV 70 | Tesvolt GmbH." https://www.tesvolt.com/en/products/ts-hv-70.html (accessed Jan. 19, 2021).

[26] H. Zahboune, S. Zouggar, G. Krajacic, P. S. Varbanov, M. Elhafyani, and E. Ziani, "Optimal hybrid renewable energy design in autonomous system using Modified Electric System Cascade Analysis and Homer software," Energy Conversion and Management, vol. 126, pp. 909-922, 2016.

[27] S. Bahramara, M. P. Moghaddam, and M. R. Haghifam, "Optimal planning of hybrid renewable energy systems using HOMER: A review," Renewable and Sustainable Energy Reviews, vol. 62, pp. 609620, 2016.

[28] A. Gupta, R. P. Saini, and M. P. Sharma, "Modelling of hybrid energy system-Part II: Combined dispatch strategies and solution algorithm," Renewable Energy, vol. 36, no. 2, pp. 466-473, 2011.

[29] A. Haffaf, F. Lakdja, R. Meziane, and D. O. Abdeslam, "Study of economic and sustainable energy supply for water irrigation system (WIS)," Sustainable Energy, Grids and Networks, vol. 25, p. 100412, 2021.

[30] W. Margaret Amutha and V. Rajini, "Techno-economic evaluation of various hybrid power systems for rural telecom," Renewable and Sustainable Energy Reviews, vol. 43, pp. 553-561, 2015. 